\title{
Synthetic studies towards the elucidation of the stereochemistry of compounds of the Cryptomoscatone D family
}

\author{
Roberta L. Drekener ${ }^{\star}$ and Ronaldo A. Pilli \\ Instituto de Química, UNICAMP, P.O. Box 6154, CEP 13083-970, Campinas, SP, Brazil \\ *drekener@iqm.unicamp.br
}

Keywords: cryptomoscatone, Keck's allylation, 1,5-anti aldol

\section{INTRODUCTION}

Natural compounds of the 5,6-dihydropyranone family, isolated from the genus Cryptocarya (Laureacae), have attracted scientific interest due to their biological activities. ${ }^{1}$ Among these compounds, we highlight Cryptomoscatone D1 and D2, isolated from C. mandiocanna, ${ }^{2}$ for which a definitive proof of structure is still lacking. In this work, we describe our synthetic efforts toward compounds 1 and 2 in order to contribute to the elucidation of the stereochemistry of Criptomoscatones D1 and D2 (Figure 1).<smiles>CC(CC(O)CC1CC=CC(=O)O1)C(O)C=Cc1ccccc1</smiles><smiles>O=C1C=CCC(CC(O)CC(O)C=Cc2ccccc2)O1</smiles>

Figure 1. Compounds isolated from $C$. mandiocanna with our proposed stereochemistry.

\section{RESULTS AND DISCUSSION}

The synthetic strategy proposed for the syntheses of isomers 1 and $\mathbf{2}$ were based on a key aldol reaction with 1,5-anti remote induction. The first approach involved the synthesis of methyl ketone $(R)-6$ in 8 steps, however in low overall yield (4.2\%) (Scheme 1).

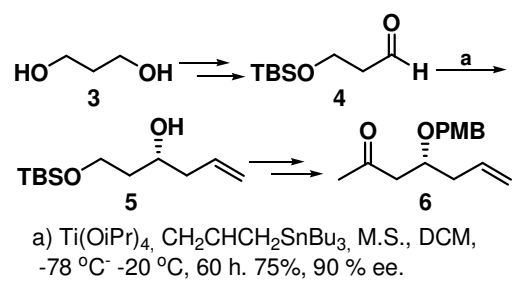

Scheme 1. Synthesis of methyl ketone 6.

The second synthetic approach led to the synthesis of methyl ketone (+/-)-9, in three steps and 54\% overall yield (Scheme 2).

$$
\begin{aligned}
& \mathrm{Ph}_{\mathrm{H}} \stackrel{\mathrm{a}}{\longrightarrow} \mathrm{CH}_{\mathrm{O}}^{\mathrm{OH}}
\end{aligned}
$$

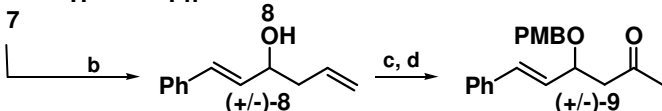

a) $80 \%, 88 \%$ ee; b) $\mathrm{CH}_{2} \mathrm{CHCH}_{2} \mathrm{MgBr}$, ether, $0{ }^{\circ} \mathrm{C}$ - r.t. $95 \%$;

c) $\mathrm{PMBCl}, \mathrm{NaH}$, DMF, r.t., $18 \mathrm{~h}, 95 \%$;

d) $\mathrm{PdCl}_{2}$ (cat), $\mathrm{CuCl}, \mathrm{O}_{2}$, DMF/ $\mathrm{H}_{2} \mathrm{O}$, r.t. $24 \mathrm{~h}, 60 \%$.
The 1,5-anti aldol reaction involving methyl ketone (+/-)-9 successfully led to the formation of the diastereoisomer (+/-)-10 (Scheme 3). The stereogenic center at C2' in (+/-)11a was established via Narasaka's ${ }^{3}$ 1,3-syn reduction while Evans ${ }^{4}$ 1,3-anti reduction afforded (+/-)-11b. After manipulation of the protecting and functional groups, $\alpha, \beta-$ unsaturated esters (+/-)-12a and (+/-)-12b were obtained with the desired $Z$ double bond via the Still-Gennari modification of the Horner-Wadsworth-Emmons olefination reaction. Cleavage of the acetonide leading to the $\alpha, \beta$ unsaturated $\delta$-hydroxyesters was achieved under mild acidic conditions, and cyclization was performed in the presence of dibutyltin oxide, in excellent yields for both steps, affording (+/-)-13a and (+/-)-13b. Removal of the $p$ methoxybenzyl ether failed using DDQ or $\mathrm{ZrCl}_{4}$ methodologies.

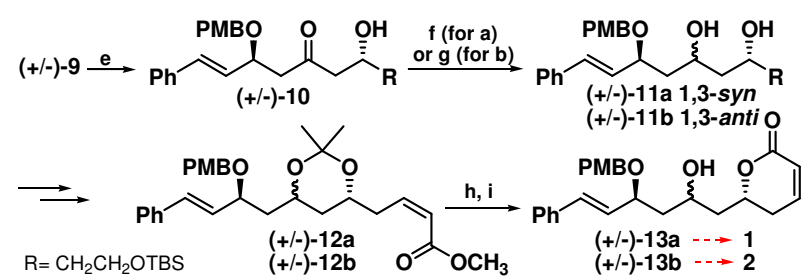

e) $(\mathrm{c}-\mathrm{Hex})_{2} \mathrm{BCl}, \mathrm{Et}_{3} \mathrm{~N}, \mathrm{DCM},-78{ }^{\circ} \mathrm{C}, 5 \mathrm{~h} ; 55 \%$; f) $(\mathrm{nBu})_{3} \mathrm{~B}, \mathrm{THF}$, synthetic air, r.t., $2 \mathrm{~h}$, $74 \%$; g) $\mathrm{Me}_{4} \mathrm{NBH}(\mathrm{OAc})_{3}, \mathrm{CH}_{3} \mathrm{CN} / \mathrm{AcOH},-78{ }^{\circ} \mathrm{C}, 4 \mathrm{~h}, 85 \%$; h) $\mathrm{HCl} 4 \%, \mathrm{CH}_{3} \mathrm{CN}, 0{ }^{\circ} \mathrm{C}$, $8 \mathrm{~h}, 98 \%$ for a and $97 \%$ for $\mathrm{b}$; i) $\mathrm{Bu}_{2} \mathrm{SnO}, \mathrm{CH}_{3} \mathrm{CN}$, reflux, $8 \mathrm{~h}, 95 \%$ for $\mathrm{a}$ and $\mathrm{b}$.

Scheme 3. Synthesis of (+/-)-13a and $b$.

\section{CONCLUSION}

This work shows an approach allowing the formation of compound (+/-)-13a in $6.7 \%$ yield and compound (+/-)-13b in $7.6 \%$ yield, from trans-cinnamaldehyde. Although our studies did not elucidate the structures of Cryptomoscatone D1 (1) and D2 (2), they are a valuable contribution for future efforts aimed to unambiguously establish the structure of these natural products.

\section{ACKNOWLEDGEMENTS}

The autors thank IQ-Unicamp, FAPESP for fellowship (R.L.D) and FAPESP and CNPq for financial support.

\section{REFERENCES}

${ }^{1}$ Cossy, J.; BouzBouz, S. Org. Lett. 2003, 5, 1995.

${ }^{2}$ Cavalheiro, A. J.; Yoshida, M. Phytochemistry 2000, 53, 811.

${ }^{3}$ Narasaka, K.; Pai, F. -C. Tetrahedron 1984, 40, 2233

${ }^{4}$ Evans, D. A.; Chapman, K. T. Tetrahedron Lett. 1986, 27, 5939.

Scheme 2. Synthesis of methyl ketone (+/-)-10.

$14^{\text {th }}$ Brazilian Meeting on Organic Synthesis $-14^{\text {th }}$ BMOS - September 01-05, 2011-Brasilia, Brazil 